\title{
English Multi-word Expressions as False Friends between German and Russian: Corpus-driven Analyses of Phraseological Units
}

\author{
Lyubov Nefedova \\ Moscow Pedagogical State University \\ 1, Malaya Pirogovskaya St., Moscow, 119991 Russia \\ lfn@mpgu . edu
}

\begin{abstract}
In this paper we outline the issue of borrowing multi-word expressions from English into German and Russian. It is established which forms of borrowed multi-word expressions (original or translated ones) predominate in contemporary German and Russian. The corpus-driven analysis of functioning of English multi-word expressions in the German and the Russian press has revealed direct borrowings and calques. The majority of the multi-word expressions borrowed from English into German over recent decades are direct loans, where as multi-word expressions borrowed from English into Russian are still calques. Uncommon direct loans in Russian often belong to professional or youth slang. In this case direct loaned multi-words expressions from English are considered in German and Russian as stylistic false friends. Direct loaned multiwords expressions can rarely have semantic differences in both languages and be semantic false friends. The text corpora comparative study helps identify semantic and stylistic false friends and provides examples for a German-Russian and Russian-German dictionary of false friends, which are represented in this paper.
\end{abstract}

Keywords: multi-word expressions, borrowing, false friends, stylistic false friends, semantic false friends, direct loans, calques

\section{Introduction}

There are a lot of intersections between German and Russian and both languages share a significant number of words of predominantly Latin and Greek origin that have the same meaning. In some cases, however, their semantics can be radically different or include different emotional or connotative components of meaning. Such cases of formal congruence and semantic non-equivalence are known as "false friends of a translator".

The only available dictionary of false friends for German and Russian languages by K. Gottlieb was published in 1972 (reprinted in 1985) [4, 5] and is increasingly obsolete in content. It does not represent the recent influence of English on German and Russian and does not contain new words and multi-word expressions from English which are new false friends.

A new dictionary on which we are working is supposed to help Russian learners of German and German learners of Russian to approach the problem of false friends more consciously to act competently in situations of intercultural contact $[7,8,10$, 11]. It constitutes the results of the corpus-driven analyses of actual use of English 
word and multi-word expressions in the contemporary German and Russian publicdiscourse. As text corpora we applied corpora of the Institute of German [16] and National Corpus of Russian [17]. The parallel German-Russian corpus could not be used because it does not contain investigated English multi-word expressions.

The main subject of this paper is the phenomenon of the influence of English on the phraseological part of contemporary German and Russian. The goal of research is to present some English multi-word expressions as false friends in German and Russian received through the corpus-driven analyses and to show that there are two kinds: semantic and stylistic.

Linguistic interpretation of collocational data from large corpora is the main method of analysis. This method helps describe multi-word expressions that develop new meanings not found in the original language.

Based on Burger's theory of phraseology we discern depending on the degree of idiomaticity nature (Idiomatizität):

- collocation (Kollokation) sich die Zähne putzen;

- part idiom (Teil-Idiom) einen Streit vom Zaun brechen;

- full idiom (Voll-Idiom) jemandem reinen Wein einschenken [2].

\section{What are False Friends between German and Russian today?}

The problem of the false friends has been dealt with in the investigations of a number of authors. Almost all observers emphasize that the false friends are pairs of words in two languages that look or sound similar, but differ significantly in meaning.

Since Haensch the concept 'false friends' is not restricted to semantic differences [6].There are false friends based solely on stylistic differences.

In Metzler Lexikon Sprache by Glück the definition of false friends is extended. Not only words but also multi-word expressions are designated as false friends ("komplexe Ausdrücke"). Besides, the feature of similarity is specified: the false friends are in two (or more) languages phonologically, graphically or morphologically similar words (or phrases). And it is accentuated that words and phrases can have different meaning gradations, reference ranges or connotations:

[...] in zwei (oder mehr) Sprachen phonologisch, graphisch oder morphologisch ähnliche Wörter (oder komplexe Ausdrücke), die jedoch unterschiedliche Bedeutung(sschattierung)en, Referenzbereiche bzw. Konnotationen haben: it. lametta Rasierklinge vs. dt. Lametta; engl. sympathetic verständnisvoll vs. dt. sympathisch usw. [3: 195-196].

Because the false friends are words or multi-word expressions in two (or many) languages the linguists speak about interlingual false friends.

The problem of phraseological, or idiomatic, false friends has not been researched exhaustively. They are defined as set phrases in two languages that have the same literal meaning but differ as regards their idiomatic meaning or their sociolinguistic and stylistic features [1].

Today the list of false friends between German and Russian is populated by words which were borrowed from English, they can lure the learners into some uncomfortable traps. Many borrowed Anglicisms in German and Russian don't mean exactly 
what one might expect. There are total false friends (they have completely different meanings), for example the words germ. Rating - rus. Рейтинг (reiting) have absolutely different meanings. The words germ. User and rus. юзер (juzer) are partial false friends. Both words have the same meaning 'somebody who uses the computer'. But the German word means also as a slang word 'somebody who regularly takes drugs'.

\section{Phraseological borrowing from English into German and Russian}

The influence of English on other European languages is so great that their vocabularies are nowadays enriching themselves not only through the borrowing of separate words from the former, but also more and more phrases or multi-word expressions entering them. Such multi-word expressions are interphraseologisms: they are used in many languages [12].

Both German and Russian phraseological systems are now considerably influenced by English: new borrowings in phraseology fill lacunae in the languages. Direct borrowings from English, not their calques are typically used by modern Germans. The Russian language also borrows lots of English phrases but not directly, most of them are calques or latent Anglicisms [13].

When addressing the issue of phraseological borrowing from English into contemporary German we can register a great number of direct borrowings. All directly borrowed multi-word expressions are word-combinations of the type adjective + noun, both components being autosemantic words. A lot of loaned multi-word expressions in German are collocations Electronic Banking, Global City, Late Show, Lean Management, Personal Trainer and part idioms: Blind Date, Daily Talk, Global Player, Soft Skills(the figurative component is underlined).Many loan phrases in German and in Russian are terms belong to technical languages, e.g. Global Player, Golden Handshake, Global Village (economics), Soft Skills (sociology), Golden Goal (sport), World Wide Web (EDP) [14].

In the dictionary of neologisms, these multi-word expressions are not always represented as phrases per se [18]. Most of them have different normative spellings: as two separate words, as one word or with a hyphen, so they can even be considered as composites, e.g. Functional food, functional food, Functionalfood, Functional-Food. Russian speakers normally try to adapt phrases borrowed from English, so calques are more popular than direct borrowings, whereas German speakers make use of either a direct loan phrase or a translated one, e.g. Functional food and the calque funktionelle Lebensmittel, the former being more preferable, though. In Russian, only the calque функциональные продукты (funktsionalnyye produkty) is in use.

Russian speakers also use lots of English loans but they are mostly loan multiword expressions which are nativized in Russian. The direct borrowing of multi-word expressions from English is not common for Russian. Some English direct multi-word expressions are used as proper names in Russian, e.g. Functional Food as the name of a company, Global Village as the name of an English language school or a fair. Such multi-word expressions are usually transliterated and are also partially adapted. 


\section{English multi-word expressions as new false friends between German and Russian: corpus-driven analyses}

Multi-word expressions from English are new false friends between German and Russian. We can reveal both types of false friends: semantic and stylistic false friends. The majority of them are stylistic false friends. I give below some examples.

The direct loaned multi-word expression Highpotential $(\mathrm{Hi}-\mathrm{Po})$ is a full idiom in German and means 'junger Akademiker, der beste fachliche und soziale Kompetenzen und damit geeignete Voraussetzungen für eine Führungsposition besonders in einem international tätigen Unternehmen hat' (a young employee who has been identified as having the best professional and social competences and suitable prerequisites for a leadership position, especially in an international company) (http://www.owid.de/artikel/315700?module=neo\&pos=16). The set expression has a figurative metonymic meaning in German and it is a neutral phrase.

I come to this conclusion based on many examples of their use in context, in contemporary German public discourse, for example:US-Forscher haben nun untersucht, was echte High Potentials ausmacht und wie man von ihnen lernen kann (Zeit Online, 12.01.2012, Die Besten unter den Besten). Nach MasterCard wechselte ich zur General Electric - zur GE Money Bank. Dort war ich High Potential und konnte mit den Besten des Unternehmens Projekte machen (NEW12/JUN.00229 NEWS, 21.06.2012, S. 68,69,70; Der Durchstarter).

The German multi-word expression hohes Potenzialis a collocation, it has a direct meaning, for example: Das Land hat hohes Potential im Blick auf die Zukunft (http://dict.leo.org/forum/viewUnsolvedquery.php?

idThread $=115540 \& l p=e n d e \& l a n g=d e)$. The translation tips of this collocation from German to English are: "the country has a promising future", "the country's future potential is high", "there is a high future potential for the country", "the country has great potential for its future", "the country is full of potential for its future"(ibid.).

The equivalent of High potential ( $\mathrm{Hi-Po}$ ) in Russian is a calque, it is a periphrasis молодой сотрудник/ молодая сотруднииа с потенциалом (molodoy sotrudnik /molodaya sotrudnitsa s potentsialom(a young employee with potential).The main sphere of use of multi-word expressions directly borrowed from English into Russian is professional discourse or youth subculture. The multi-word expression xaй потеншл (хай-по) (transliteration of the English set expression) is used in Russian as a slang phrase: Хай потеншл решают задачи с помощью микролёнинговых программ (https://vk.com/id4943278) High potentials (Hi-Po's) solve tasks with the help of mikro learning programmes. The multi-word expression is written like an English phrase too: мы планируем сосредоточиться на областях развития лидерства топ-менеджеров, менеджеров среднего звена и high potentials (we are planning to focus on areas of development of leadership of head-managers, midlevel managers and high potentials) (http://www.trainings.ru/library/articles/?id=9052).

A striking example of a loan multi-word expression borrowed from English into Russian which has undergone a semantic revaluation is elektronnyy kesh (electronic cash).In German the expression Electronic Cash has a meaning 'bargeldlose Zahlungsweise mittels

einer

EC-Karte“ 
(http://www.owid.de/artikel/298337?module=neo\&pos=13), for example: In zahlreichen westeuropäischen Ländern wird auch Electronic Cash akzeptiert (A00/JUN.41196 St. Galler Tagblatt, 15.06.2000, Ressort: TB-LBN (Abk.); Ohne Not auch ohne «Nötli»).

The Anglicism electronic cash corresponds to two multi-word expressions in Russian, i.e. электронные деньги (elektronnyye dengi) (money) or электроннье платежи (elektronnyye platezhi) (payments) and электронный кэи (elektronnyy kesh). The direct loaned multi-word expression phrase elektronnyy kesh acquires a new meaning in Russian -not 'electronic money' like in English and German, but 'money for gangsters, drug traffickers, terrorists, killers and corrupt officials' [Nefedova, Polyakov 2014].An example from Russian: “... задачей Центрального банка России является твердое заявление, что электронный кэш в Россию не будет допущен" ... the task of the Central Bank of Russia is to firmly state that electronic cash will not be allowed in Russia (http://www.ereading.club/chapter.php/84362/65/Yurovickiii_Denezhnoe_obrashchenie_v_epohu_ peremen.html).

The analysis of various contexts of use of the multi-word expressions electronic cash and elektronnyy kesh in German and Russian text corpora allows identifying them as semantic false friends.

Further corpus-driven analyses of English multi-word expressions in German and Russian can give other examples of semantic and stylistic differences and the corpora "should be the sole source of our hypotheses about language" [15].

Such multi-word expressions are idiomatic semantic false friends, but they are not represented in the only available dictionary of false friends for German and Russian by K. Gottlieb, published 1972, which is becoming increasingly obsolete in content. A new dictionary is supposed to help Russian learners of German and German learners of Russian approach the problem of false friends more consciously and act more competently in situations of intercultural contact.

\section{English multi-word expressions in the new dictionary of false friends for German and Russian}

The new dictionary of false friends for German and Russian will include English multi-word expressions that are semantic and stylistic false friends. The content of the dictionary will be so arranged that it will be used by Russian learners of German and German learners of Russian alike.

Let us look at two examples of how multi-word expressions will look like in the new dictionary of false friends between German and Russian.

Each article in the dictionary designates formal consentaneous pairs of words and has a cross construction. In the German part of the dictionary, a corresponding German lexical unit is accompanied by a basic grammatical description. It has a canceled translation which is automatically assumed but could be a trap for the learner, and finally a correct translation. The word use is illustrated with an example from everyday speech which is translated into Russian.

In the Russian part, a reverse translation of the correct Russian equivalent is given, backed with an example of its use. 
Presentation of multi-word expressions as semantic false friends

$\mathbf{E}$

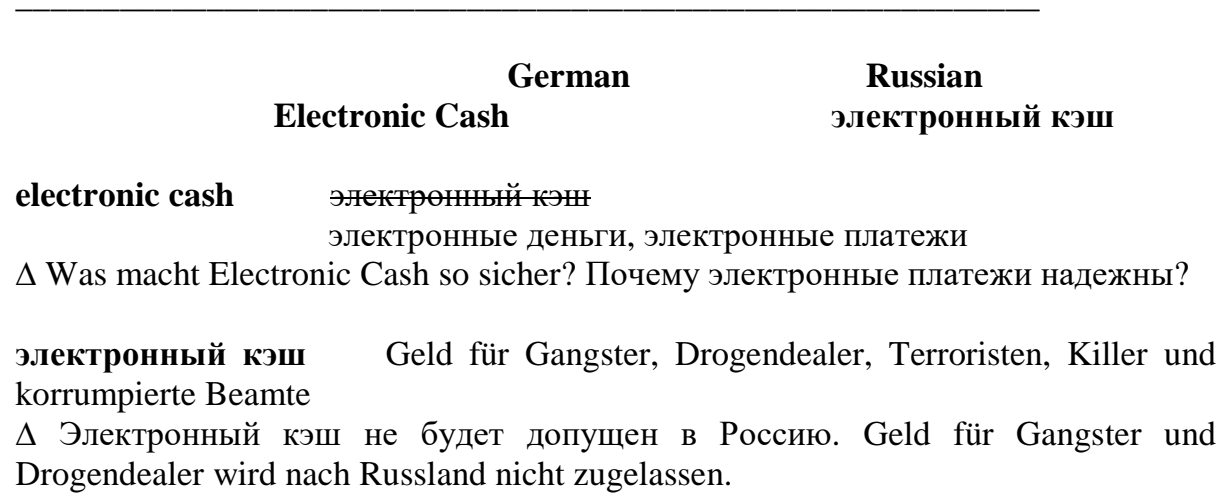

Presentation of multi-word expressions as stylistic false friends

H

High Potential

\section{German Russian хай потеншл (хай-по) / high potential}

High Potential хай нөтеншл/ high potential(professional / youth slang) молодой сотрудник / молодая сотрудница с потенциалом $\Delta$ Nach dem Studium kam er als High Potential zu einer Bank und war innerhalb weniger Jahre zum Projektleiter aufgestiegen. После учебы как молодой сотрудник с потенциалом он стал работать в банке и через несколько лет стал руководителем проекта.

хай потеншл / high potential (professional / youth slang) High Potential $\Delta$ Хай-по или хай потеншл - новый тренд в управлении кадрами. High Potential ist ein neuer Trend in der Personalverwaltung.

Stylistic differences between English multi-word expressions in German and in Russian are labeled professional / youth slang.

The dictionary will give examples of multi-word expressions in use from text corpora of the contemporary German and Russian public discourse. 


\section{Conclusion}

In the light of the growing internationalization of German and Russian the problem of false friends gets more relevant. Considering that the vocabulary of both languages develops in the ethnocentric cultures, the number of false friends is increasing rapidly. New false friends in German and Russian are borrowed Anglicisms, but they are not reflected in the dictionary of false friends for German and Russian. In addition, there are more new multi-word expressions which are used differently. That is why one of the important goals of modern linguistics is to update the dictionary of false friends to the current standard of lexicography and include English multi-word expressions.

This paper illustrates semantic and stylistic differences of meaning of English multi-word expressions in German and Russian and also some new forms of presenting of phraseological units in the German-Russian dictionary of false friends based on corpus-driven approach. Corpus linguistics is a research approach that supports empirical investigations of language use, primarily of new lexical units, and serves as a reliable source of material for lexicography.

\section{References}

1. Al-Wahy, A. S.: Idiomatic false friends in English and Modern Standard Arabic. Babel 55 (2), 101-123 (2009).

2. Burger, H.: Phraseologie: Einführung am Beispiel des Deutschen (Grundlagen der Germanistik (GrG), Band 36). 3. Auflage. Erich Schmidt Verlag GmbH \& Co, Berlin (2007).

3. Glück, H. (ed.): Metzler Lexikon Sprache. 4. aktualisierte und überarbeitete Auflage. J.B. Metzler, Stuttgart/Weimar (2010).

4. Gottlieb, K.H.: Deutsch-Russisches und Russisch-Deutsches Wörterbuch der „Falschen Freunde des Übersetzers“. Sovyetskaya Entsiklopediya, Moskva (1972).

5. Gottlieb, K.H.: Sprachfallen im Russischen: Wörterbuch der „falschen Freunde“ Deutsch und Russisch: Ein Lern- und Nachschlagewerk. Hueber, Ismaning (1985).

6. Haensch, G.: „Faux amis“. In: Lebende Sprachen: Zeitschrift für fremde Sprachen in Wissenschaft und Praxis. Fachblatt des Bundesverbandes der Dolmetscher und Übersetzer 1, 16 (1956).

7. Nefedova, L.: Lexikografie und Interkulturalität. Zum Projekt für ein deutsch-russisches und russisch-deutsches Wörterbuch der falschen Freunde des Übersetzers. In: SchellerBoltz, D., Weinberger, H. (eds.) Lexikografische Innovation - Innovative Lexikografie. Bi- und multilinguale Wörterbücher in Gegenwart und Zukunft: Projekte, Konzepte, Visionen, S. 231-247. Olms Verlag, Hildesheim/Zürich/New York (2017).

8. Nefedova, L.: Sprachfallen: Wie kann man sie umgehen? Über den Umgang mit ,falschen Freunden" des Deutschen und des Russischen. In: Földes, Cs. (ed.) Interkulturelle Linguistik als Forschungsorientierung in der mitteleuropäischen Germanistik. (Beiträge zur interkulturellen Germanistik; 8), S. 149-165. Narr Francke Attempto, Tübingen (2017).

9. Nefedova, L., Polyakov, O.: Set Expressions Borrowed from English into German and Russian: Direct Loans or Calques? In: Gural, S. (ed.) Procedia - Social and Behavioral 
Sciences. The XXVI Annual International Academic Conference, Language and Culture, 27-30 October 2015, vol. 200, pp. 83-86 (2015).

10. Nefedova, L.: Russian-German and German-Russian Dictionary of False Friends. In: Karpova O.M., Shilova, E.A. (eds.) Heritage Lexicography as Supporting Tool for International Council for Monuments and Sites (ICOMOS): Proceeding of the International Workshop. Florence, July 21-23, 2014, pp. 71-74. Ivanovo State University, Florence/Ivanovo (2014).

11. Nefedova, L.: O novom tipe nemetsko-russkogo i russko-nemetskogo slovarya "lozhnyih druzey perevodchika: $\mathrm{k}$ voprosu ob innovatsiyah v leksikografii. In: Kitadzë M., Minasyan, S. (eds.) Sotsiokulturnyie i filologicheskie aspektyi v obrazovatelnom i nauchnom kontekste, pp. 410-415. University Kyoto Sangë, Kyoto (2014).

12. Nefedova, L.: On the Use of Interphraseologisms in the Journalistic Discourse of German and Russian Linguocultures. In: Gural, S. (ed.) Procedia - Social and Behavioral Sciences. The XXV Annual International Academic Conference, Language and Culture, 20-22 October 2014, vol. 154, pp. 130-137 (2014).

13. Nefedova, L., Polyakov, O.: On Some Aspects of the Borrowing of Phrases from English into German and Russian. In: Arsenteva E. (ed.) Phraseology in Multilingual Society, pp. 141-155. Cambridge Scholars Publishing, Newcastle upon Tyne (2015).

14. Nefedova, L.: $\mathrm{Zu}$ einigen Aspekten der phraseologischen Entlehnungen aus dem Englischen im heutigen Deutsch. In: Arsenteva E. (ed.) Phraseology in Multilingual Society. Sbornik statey mezhdunarodnoy frazeologicheskoy konfrentsii „Europhras“ 19-22 avgusta 2013, vol. 1, pp. 200-207. Tatarskoe respublikanskoe izdatelstvo „KHETER”, Kazan (2013).

15. Tognini-Bonelli, E.: Corpus Linguistics at Work. (= Studies in Corpus Linguistics 6). Amsterdam/Philadelphia (2001).

16. Deutsches Referenzkorpus, https://cosmas2.ids-mannheim.de/cosmas2-web/, last accessed 2017/06/15.

17. Russian National Corpus, http://www.ruscorpora.ru/, last accessed 2017/06/15.

18. Neologismenwörterbuch, http://www.owid.de/wb/neo/start.html, last accessed 2017/06/15. 